\title{
The Relationship between Nutritional Status of Pregnant Women and Stunted Children
}

\section{Ida Royani $^{1}$, Nasrudin Andi Mappaware ${ }^{2}$, Sidrah Darma ${ }^{3}$, Nurfadhillah Khalid ${ }^{4}$, Dian Fahmi Utami ${ }^{*} *$}

1 Division of Nutrition/Faculty of Medicine/ Universitas Muslim Indonesia/Indonesia

2 Department of Obstetrics and Gynecology /Faculty of Medicine/Universitas Muslim Indonesia/Indonesia

3 Division of Nutrition / Faculty of Medicine /Universitas Muslim Indonesia/Indonesia

4 Department of Pharmacology / Faculty of Medicine / Universitas Muslim Indonesia/Indonesia

5 Faculty of Medicine / Universitas Muslim Indonesia/Indonesia

*Corresponding Author. E-mail: dian.fahmiutami@umi.ac.id, Mobile number: 085241828716

ABSTRACT
Introduction: The nutritional status of pregnant women has a significant impact on the fetus's health and development.
Low birth weight can be caused by womb growth problems. Research in Nepal shows that babies with low birth weight
have a higher risk of becoming stunted. West Sulawesi is the most populous province in Central Indonesia, with a
population of $39.7 \%$. In Mamuju District, West Sulawesi, the relationship between stunted babies and maternal
nutritional status during pregnancy was investigated.
Methods: Cross sectional analytic survey with a retrospective approach. Data processing using the chi square test.
The population in this study was 20.039 people. Total sampling was used to collect nutritional status data of children
under the age of five in West Sulawesi province from February to June 2020. In this study, 88 people were sampled,
all of whom were mothers of stunted children aged 2 to 5 Years old and who had a KIA book during pregnancy.
(Continued on next page)

\section{Article history:}

Received: 12 February2021

Accepted: 26 April 2021

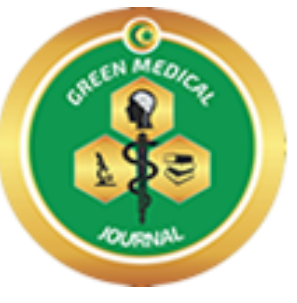

Published by:

Faculty of Medicine

Universitas Muslim Indonesia

Mobile number:

+6282197210007

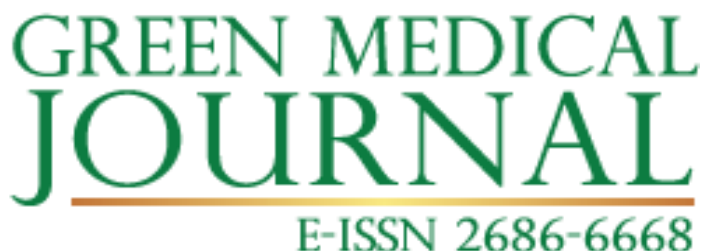

Address:

J1. Urip Sumoharjo Km. 5, Makassar

South Sulawesi, Indonesia

Email:

greenmedicaljournal@umi.ac.id 
(Continued from previous page)

Results: The results of statistical tests showed that the p value of nutritional status with BMI and LILA 0.000 and the $\mathrm{p}$ value of HB levels 0.066 . There was a link between pregnant women's nutritional status and LILA, but not between HB levels and stunting.

Conclusion: The conclusion of this study is that there is a relationship between the nutritional status of pregnant women based on BMI and LILA and the incidence of stunting in Mamuju Regency, West Sulawesi Province.

Keywords: Nutritional status; BMI; stunting

\section{Introduction}

Nutritional issues must be considered even while the baby is still in the womb. The nutritional status of pregnant women has a significant impact on the growth and development of the fetus. Stunting or short children under the age of five are toddlers with chronic nutritional problems who have nutritional status based on length or height according to age when compared to the 2005 WHO-MGRS (Multicentre Growth Reference Study) standard, with a z-score of less than -2SD, and if the z-score is less than-3SD, they are classified as very short under five (Pusdatin, 2015).(1,2)

In developing countries, including Indonesia, nutrition is still a major public health problem and a cause of death for mothers and children. The mortality rate for infants and mothers and babies with low birth weight (LBW) is essentially also determined by the nutritional status of pregnant women. Pregnant women with poor nutritional status or experiencing KEK (Chronic Energy Deficiency) tend to give birth to LBW babies and are faced with a greater risk of death compared to babies born to mothers with normal weight. There are several ways that can be used to determine the nutritional status of pregnant women, including monitoring weight gain during pregnancy, measuring the upper arm circumference (LILA), and measuring HB levels. $(3,4)$

The health and development of the fetus are greatly influenced by the nutritional status of pregnant women. Low birth weight can be caused by womb growth problems (WHO, 2014). Babies born with a low birth weight have a higher risk of becoming stunted, according to Nepalese research (Paudel, et al., 2012). Stunting is also linked to the length of time a baby spends in the womb. According to research conducted in Kendal, babies born with short birth lengths have a higher risk of stunting as toddlers (Meilyasari and Isnawati, 2014). Exclusive breastfeeding for children under the age of five is another factors linked to toddlers stunting who are not exclusively breastfed for 6 months have a high risk of stunting, according to research conducted in Southern Ethiopia (Fikadu, et al., 2014).(5-8)

In Indonesia, East Nusa Tenggara is a province with the highest prevalence of infants with stunting, 
Green Medical Journal Vol.3 Issue: 1 (April, 2021

e-ISSN: 2686-6668)

namely $42.6 \%$ (Riskesdas, 2018). The province with the second largest stunted infants in Indonesia is West Sulawesi and is the highest province in Central Indonesia, reaching 39.7\%. This number consists of very short toddlers reaching $14.7 \%$ and $25 \%$ short toddlers. $(9,10)$

Because of the high incidence of stunting in Central Indonesia, particularly in West Sulawesi Province and Mamuju Regency, the authors are interested in conducting research on the relationship between maternal nutritional status during pregnancy and the incidence of stunting babies in Mamuju Regency, West Sulawesi, in order to reduce stunting in the West Sulawesi region.

\section{Method}

This type of research is an analytical survey. The research design used was a cross sectional approach (cross sectional) with a retrospective approach in which the cause and effect variables (related and independent variables) were measured at the same time and moment (point time approach).

The study took place in the Mamuju Regency of West Sulawesi Province. According to LP2S UMI's schedule, the research took place between February and June 2020. The study's participants were stunted children in Mamuju Regency, West Sulawesi Province. The population in this study was 20.039 people. The sampling technique used in this study was total sampling, with a total sample size of 88 people who met the inclusion criteria of mothers with stunted children aged 2 to 5 Years and who had a KIA book during pregnancy. Questionnaires and observation sheets were used as data collection instruments in this study. The chi square test was used in this data analysis.

The operational definition of stunting in this study is children aged 2-5 Years with nutritional status based on Body Length (BL)/ Age (A) or Body Height (BH) / Age (A) z-score <-2SD to -3SD for short status and $<-3 \mathrm{SD}$ for very short status. Circumference of the upper arm (LILA) is a measurement of the nutritional status of pregnant women by measuring the circumference of the upper arm, which is divided into normal 23-33 $\mathrm{cm}$, under nutrition $<23 \mathrm{~cm}$ and over nutrition $>33 \mathrm{~cm}$. BMI (Body Mass Index) is a measurement of the nutritional status of pregnant women by measuring body weight $(\mathrm{kg})$ and height $(\mathrm{m} 2)$. Hemoglobin levels are blood hemoglobin levels with normal levels> $10.5 \mathrm{mg} / \mathrm{dl}$.

\section{Results}

The results of this stunting study were derived from simple random sampling of data on the nutritional status of children under the age of five in West Sulawesi province in February-June 2020. In this study, a total of 88 people were sampled, all of whom were mothers with stunted children aged 2 to 5 . The age range was chosen because the effect of malnutrition on height takes a long time to manifest.

In this study, preliminary data were obtained regarding the nutritional status of children in West Sulawesi Province as follows: 
Green Medical Journal Vol.3 Issue: 1 (April, 2021

e-ISSN: 2686-6668)

Table 1. Initial nutritional status data for children in West Sulawesi based on their height and age.

\begin{tabular}{|c|c|c|c|c|c|c|c|c|c|c|c|c|}
\hline \multirow{3}{*}{ Regency/City } & \multicolumn{4}{|c|}{ Very Short } & \multicolumn{4}{|c|}{ Short } & \multicolumn{4}{|c|}{ Normal } \\
\hline & \multicolumn{2}{|c|}{$0-2$ Years } & \multicolumn{2}{|c|}{ 2-5 Years } & \multicolumn{2}{|c|}{$0-2$ Years } & \multicolumn{2}{|c|}{ 2-5 Years } & \multicolumn{2}{|c|}{$0-2$ Years } & \multicolumn{2}{|c|}{$2-5$ Years } \\
\hline & $\mathrm{L}$ & $\mathrm{P}$ & $\mathrm{L}$ & $\mathrm{P}$ & $\mathrm{L}$ & $\mathrm{P}$ & $\mathrm{L}$ & $\mathrm{P}$ & $\mathrm{L}$ & $\mathrm{P}$ & $\mathrm{L}$ & $\mathrm{P}$ \\
\hline Majene & 335 & 221 & 797 & 622 & 396 & 314 & 967 & 916 & 1354 & 1302 & 1687 & 1646 \\
\hline $\begin{array}{l}\text { Polewali } \\
\text { Mandar }\end{array}$ & 467 & 285 & 1341 & 980 & 998 & 673 & 2447 & 2037 & 4315 & 4109 & 6419 & 5892 \\
\hline Mamasa & 219 & 113 & 460 & 289 & 308 & 222 & 799 & 615 & 1234 & 1089 & 2646 & 2419 \\
\hline Mamuju & 470 & 393 & 869 & 740 & 347 & 264 & 640 & 580 & 2766 & 2467 & 3861 & 3366 \\
\hline Mamuju Utara & 195 & 85 & 456 & 339 & 273 & 186 & 921 & 752 & 1720 & 1690 & 2981 & 2854 \\
\hline $\begin{array}{l}\text { Mamuju } \\
\text { Tengah }\end{array}$ & 33 & 19 & 116 & 72 & 81 & 37 & 198 & 152 & 541 & 465 & 1080 & 841 \\
\hline Total & 1719 & 1116 & 4039 & 3042 & 2403 & 1696 & 5972 & 5052 & 11930 & 11122 & 18674 & 1701 \\
\hline
\end{tabular}

Source: Primary Data

Table 2. Nutritional characteristics of pregnant women with stunted babies based on BMI

\begin{tabular}{lcc}
\hline Characteristics & n & \% \\
\hline Body Mass Index & 53 & 60.2 \\
Less & 32 & 36.4 \\
Normal & 3 & 3.4 \\
Overweight & 0 & 0 \\
Obesity & &
\end{tabular}

\section{Circumference of The Upper Arm}

Less

Normal

29

Obesity

0

0

\section{HB}

No Anemia

Anemia
76

12
86,4

13,6

\section{Total}

88

100.0

Source: Primary Data 


\begin{tabular}{lccccccc} 
& $\mathbf{n}$ & $\mathbf{\%}$ & $\mathbf{n}$ & $\mathbf{\%}$ & $\mathbf{n}$ & $\mathbf{\%}$ & \\
\hline Less & 8 & 9,10 & 51 & 58 & 59 & 67,1 & \\
Normal & 28 & 31,82 & 1 & 1,14 & 29 & 32,9 & 0.000 \\
Obesity & 0 & 0 & 0 & 0.0 & 0 & 0 & \\
& & & & & & & \\
\hline Total & $\mathbf{3 6}$ & $\mathbf{4 0 . 9}$ & $\mathbf{5 2}$ & $\mathbf{5 9 . 1}$ & $\mathbf{8 8}$ & $\mathbf{1 0 0 . 0}$ &
\end{tabular}

Sources: Primary Data

Based on the primary data in table 4, it is found that with a malnutrition status based on LILA, it is found that the group of mothers with less nutritional status is 59 people with 51 people (58\%) having very short babies and 8 people $(9.10 \%)$ with short babies. While in the group of mothers with normal nutritional status as many as 29 people with 28 people $(31.82 \%)$ having short babies and 1 person $(1.14 \%)$ with very short babies. The statistical test yielded a $\mathrm{p}$ value of 0.05 , indicating that there is a link between maternal nutritional status during pregnancy as measured by LILA and the incidence of stunting.

Table 5. Analysis of the effect of nutritional status based on HB to the incidence of stunting

\begin{tabular}{|c|c|c|c|c|c|c|c|}
\hline \multirow{3}{*}{ Nutritional Status } & \multicolumn{4}{|c|}{ Stunting } & & & \multirow{3}{*}{$p$} \\
\hline & \multicolumn{2}{|c|}{ Short } & \multicolumn{2}{|c|}{ Very Short } & \multicolumn{2}{|c|}{ Total } & \\
\hline & $\mathbf{n}$ & $\%$ & $\mathbf{n}$ & $\%$ & $\mathbf{n}$ & $\%$ & \\
\hline Non Anemia & 34 & 38,63 & 42 & 47,73 & 76 & 86,36 & \\
\hline Anemia & 2 & 2,28 & 10 & 11,36 & 12 & 13,64 & 0.066 \\
\hline Total & 36 & 40,91 & 52 & 59,09 & 88 & 100,00 & \\
\hline
\end{tabular}

Sources: Primary Data

Based on the primary data in table 5, it is found that with less nutritional status based on HB levels, 76 people with HB levels are not anemic with 42 people (47.73\%) having very short babies and 34 people $(38.63 \%)$ with babies. short. Whereas in the group of mothers with anemia as many as 12 people with 10 people $(11.36 \%)$ having very short babies and 2 people $(2.28 \%)$ with short babies. The results of statistical tests showed that the value of $p \Rightarrow 0.05$, which means that there is no relationship between maternal nutritional status based on HB levels during pregnancy and the incidence of stunting.

\section{Discussion}

Stunting is a complex health problem, which can be linked by several factors that are currently still developing. such as health. economic. social and cultural factors. As in this studv. data from various factors 
were obtained from respondents both from medico social factors, medico obstetra and nutritional status which focused on the condition of the mother during pregnancy.

The mother's nutritional status was determined using her LILA during pregnancy, her BMI, and her HB level. Based on the results of statistical tests, a p value of 0.05 was obtained, indicating that there is a significant relationship between pregnant women's nutritional status as measured by LILA and BMI and stunting status in children aged 2 to 5 Years in Mamuju district, West Sulawesi Province. This is in line with Ringgo et al's (2019) findings, which show that the incidence of stunting is linked to the nutritional status of mothers during pregnancy. In another study also conducted by Sukmawati (2018), it was stated that there was a relationship between the nutritional status of mothers during pregnancy and the incidence of stunting and LBW. $(11,12)$

The statistical test of the relationship between maternal HB levels during pregnancy yielded a p value > 0.05, indicating that there is no significant relationship between HB levels and stunting status in Mamuju Regency children aged 2 to 5. This is in line with a study conducted in Semarang by VindaNur et al (2019), which found no link between HB levels and the incidence of stunting. Another study conducted in Yogyakarta by Kristiana et al (2016) found no link between maternal hemoglobin levels during pregnancy and the incidence of stunting in children. Factors that can affect hemoglobin levels are the intake of nutrients such as vegetables, fruits and foods that contain iron. $(13,14)$

A healthy baby is more likely to be born if the mother's nutritional status is good during pregnancy. The nutritional status of pregnant women, like that of the general population, is a physical condition that results from the consumption, absorption, and utilization of various macro and micronutrients. Because the pregnancy process causes physiological changes including hormonal changes and increased blood volume for fetal development, pregnant women must also increase their nutrient intake to meet these needs (Ministry of Health, RI 2018). The incidence of stunting is also influenced by various factors from the child, such as the presence of infectious diseases, exclusive breastfeeding, and the nutritional intake obtained.(13-15)

\section{Conclusion}

According to the findings, there was a link between maternal nutritional status during pregnancy as measured by BMI and LILA and the incidence of stunting, but no link between nutritional status as measured by HB levels and the incidence of stunting in Mamuju Regency, South Sulawesi Province.

\section{Acknowledgments}

We would like to express our deepest gratitude to the leadership of the Universitas Muslim Indonesia, especially to the Chairperson of LP2S Prof. Dr. H. Syahnur Said, SE, MS who gave us the opportunity in the form of a forum, support and financial assistance for the implementation of this research. We would also like to thank the Local Government of Mamuju Regency for allowing us to conduct research in Mamuju Regency 
and always helping during this research process. We also do not forget to express our deepest gratitude to the leadership of the Faculty of Medicine at Universitas Muslim Indonesia, who contributed a lot in the preparation of this research, as well as the lecturers, colleagues and friends who continuously supported us so that this research could be completed. . Hopefully through this research, Allah SWT will give us useful knowledge, solutions to all problems and of course health to anyone who reads it.

\section{References}

1. Zaif RM, Wijaya M, Hilmanto D. Hubungan antara Riwayat Status Gizi Ibu Masa Keha milan dengan Pertumbuhan Anak Balita di Kecamatan Soreang Kabupaten Bandung. J Sist Kesehat. 2017;2(3):15663.

2. Mugianti S, Mulyadi A, Anam AK, Najah ZL. Faktor Penyebab Anak Stunting Usia 25-60 Bulan di Kecamatan Sukorejo Kota Blitar. J Ners dan Kebidanan (Journal Ners Midwifery). 2018;5(3):268-78.

3. Ni'mah K, Nadhiroh SR. Faktor yang Berhubungan dengan Kejadian Stunting pada Balita. Media Gizi Indones. 2015;13-9.

4. W. Ferial E. Hubungan antara Status Gizi Ibu berdasarkan Ukuran Lingkar Lengan Atas (LIA) dengan Berat Badan Lahir Bayi di RSUD Daya Kota Makassar. 2012;2(3):11-22.

5. Setiawan E, Machmud R, Masrul M. Faktor-Faktor yang Berhubungan dengan Kejadian Stunting pada Anak Usia 24-59 Bulan di Wilayah Kerja Puskesmas Andalas Kecamatan Padang Timur Kota Padang Years 2018. J Kesehat Andalas. 2018;7(2):275.

6. Zahriany AI. Pengaruh Bblr Terhadap Kejadian Stunting Pada Anak Usia 12-60 Bulan Di Wilayah Kerja Puskesmas Tanjung Langkat Years 2017. J Ris Hesti Medan Akper Kesdam I/BB Medan. 2017;2(2):129.

7. Irsyad, Aufa. Status Gizi Ibu Hamil. Banda Aceh; 2016.

8. Amini A. Hubungan Kunjungan Antenatal Care (ANC) dengan Kejadian Stunting pada Balita Usia 1259 Bulan di Kabupaten Lombok Utara Provinsi NTB Years 2016. 2016;2-22. Available from: file:///C:/Users/Acer/Downloads/anc.pdf

9. Mamuju DKK. Skrining Stunting di Kabupaten Mamuju. Sulawesi Barat. 2019.

10. Indonesia KKR. Situasi Balita Pendek (Stunting) di Indonesia. Jakarta; 2018.

11. Sukmawati, Hendrayati, Chaerunnimah, Nurhumaira. Status Gizi Ibu Saat Hamil, Berat Badan Lahir Bayi dengan Stunting Pada Balita. Media Gizi Pangan. 2018;25:18-25.

12. Alfarisi R, Nurmalasari Y, Nabilla S. Status Gizi Ibu Hamil Dapat Menyebabkan Kejadian Stunting Pada Balita. J Kebidanan Malahayati. 2019;5(3):271-8.

13. Apriningtyas V, Kristini T. Faktor Prenatal yang Berhubungan dengan Kejadian Stunting Anak Usia 624 Bulan. J Kesehat Masy Indones Semarang. 2019;

14. Warsini KT, Hadi H, Nurdiati DS. Riwayat KEK dan anemia pada ibu hamil tidak berhubungan dengan kejadian stunting pada anak usia 6-23 bulan di Kecamatan Sedayu, Bantul, Yogyakarta CED and maternal anemia did not associate with stunting in children 6-23 months in Sedayu Subdistrict, Bantu. 2016;(44).

15. Aridiyah FO, Rohmawati N, Ririanty M. Faktor-faktor yang Mempengaruhi Kejadian Stunting pada Anak Balita di Wilayah Pedesaan dan Perkotaan. e-Jurnal Pustaka Kesehat. 2015;3(1). 